\title{
Pharmaceutically active secondary metabolites of newly isolated actinobacteria from two Cameroonian soils
}

\author{
Steve Takoukam Toukam ${ }^{1}$, Albert Ngakou ${ }^{1}$, Samira R. Mansour ${ }^{2 *}$ \\ ${ }^{1}$ Department of Biological Sciences, Faculty of Science, University of Ngaoundere, Cameroon \\ ${ }^{2}$ Botany Department, Faculty of Science, Suez Canal University, Ismailia, Egypt
}

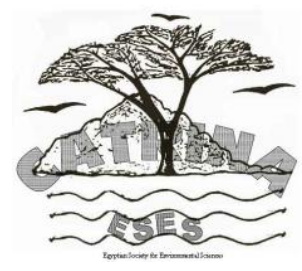

\begin{abstract}
Clinical infectious diseases are a major public health concerns worldwide, particularly in developing countries, where access to health care is extremely limited. In a context of increased development of antibiotic-resistant microorganisms, extensive research efforts, to explore novel antimicrobial from newly isolated organisms, are in need. Therefore, our study was carried out to isolate actinobacteria, for the first time, from two different soils collected from Cameroon. Fifty-eight out of 82 isolates of actinobacteria showed antimicrobial activity against human pathogens based on agar disc overlay bioassay. Meanwhile, the excreted metabolites of these actinobacteria were also tested for antimicrobial activity using agar disc diffusion test. Nine Gram-positive and negative human bacterial pathogens were used. One fungal pathogen was also tested. Our results showed that the most active actinobacterial isolates are belonging to the genera: Microtetraspora sp. (CSU3), Nocardiopsis sp. (CSU5), Streptomyces sp. (PSP3, PSU28 and PSU30), and Micromonospora sp. (CSD50). Streptomyces sp. and Actinomadura sp. isolates were the most dominant genera producing potent antimicrobial secondary metabolites, indicating that Streptomycetes-phenotype isolates are providing high quality metabolites for drug discovery purposes. Natural occurring biochemical compounds excreted in liquid media were also tested and proved the presence of alkaloids and tannins compounds.
\end{abstract}

ABSTRACT

Keywords: Soil actinobacteria, Bioactive metabolites, Antimicrobial activity, Cameroonian soil..

\section{INTRODUCTION}

Lately, the chances of discovering novel biologically active molecules from various soil actinobacteria have received much attention since the development of multi-resistant human bacterial pathogens. The isolation of different actinobacteria from newly explored soil or habitats can be a source for novel antimicrobial compounds. Poorly exploited areas are essential for the discovery of novel actinobacteria and their metabolites. Extreme ecosystems can also be a good source of untapped microorganisms that are able to produce novel bioactive compounds for human's health and of industrial interest. These compounds are natural products of microbial metabolism known as secondary metabolites. They are produced by microbes during their stationary growth phase and are concomitant with a switch in energy and carbon flux away from biomass production toward the production of small bioactive molecules. Therefore, they are one of the main outcomes from fermentation bioindustries in various fields. Simply the metabolites of microorganisms can be defined as different kinds of substances that are essential to the metabolism of an organism. Each organism can produce a huge variety of metabolites, which can be generally categorized into primary and secondary metabolites. Primary metabolites serve as a key role in the survival of microorganisms and principally play an active role in microbial growth, while secondary metabolites are not involved in the normal growth, but in the microbial defense against harsh conditions. They include alkaloids, steroids, phenolic, flavonoids and other nitrogenous compounds. They are primarily used in the pharmaceutical industry for their powerful capability as antimicrobial drugs, since they inhibit infectious diseases for human and animals, and thus increase their life expectancy (Tamura et al., 1997). A variety of Actinobacteria, which are particularly illustrated by their high effectiveness in the secondary metabolism, have remarkable diversity of metabolites that can be used for different pharmaceutical purposes (Overbye and Barret, 2005).

Actinobacteria are Gram-positive microaerophilic to aerobic bacteria. They are distinguished by their unique morphology, DNA with high CG content and their unique way for reproduction. They constitute one of the largest bacterial phyla that have ubiquitous distribution in different habitats. Although some show pleomorphic and even coccoid elements, they characteristically have a filamentous mycelium. They also have extensive diverse secondary metabolisms that represent about two-thirds of all naturally derived antibiotics in current clinical use, in addition to many anticancer, anthelmintic, and anti-fungal compounds (Lacey, 1997). Although heavily studied over the past three decades on the active roles of actinobacteria activity, they continued to prove themselves as reliable sources of novel bioactive compounds. Meanwhile, the bioactive secondary metabolites produced by actionbacteria have been confirmed to possess novel antibacterial, antifungal, antioxidant, neurogenic, anticancer, anti-algal, anthelmintic, anti-malarial and antiinflammatory activities (Chaudhary et al., 2013). They significantly also contribute to the turnover of complex biopolymers, such as lignocellulose, hemicellulose, pectin, keratin, and chitin (Vijayakumar et al., 2007). The production of secondary metabolites is varied with the isolate, growth condition including carbon and nitrogen sources, as well as $\mathrm{pH}$, oxygen level and temperature (Sahaya and Dhanaseeli, 2012). According to Newman et al., (2003), 80\% of drugs used in the treatment of various diseases are of natural origin, of 
which nearly $62 \%$ of anti-cancer molecules and $78 \%$ of antimicrobial are used in the current therapy. Actinobacteria are considered the major sources of these drugs.

The use of actinobacteria in industrial and pharmaceutical purposes offers a new area to be explored by researchers and puts actinobacteria under the most extreme conditions of prime concern. Cameroonian soils are rich with microbial communities and no significant studies have been undertaken so far to assess these communities, in particular for actionbacteria that exist in different habitats. Therefore, to address this issue, two soil types were collected and evaluated for their actinobacterial communities that are able to produce antimicrobial activity against human pathogens. In the meantime, the biochemical screening of secondary metabolites produced by isolated actionbacteria was also considered and discussed.

\section{MATERIALS AND METHODS}

\section{Sample collection and studied sites}

Soil samples were collected from Ngaoundere, located in Adamawa, Cameroon. Soil samples were collected, after removal of $1 \mathrm{~cm}$ of soil that contains organic litter, using dry clean sterile polythene bags along with sterile soil core of $10 \mathrm{~cm}$ diameter following the technique described by Mansour et al., (2015). Two different sites; one from vehicles repairing station and the other from a composting site at the University of Ngaoundere campus, were considered for our investigation.

\section{Soil pretreatment}

The collected soil samples were air dried, sieved (mesh size, $2 \mathrm{~mm}$ ) to remove plant debris, and then subjected to physiochemical analyses and actinobacteria isolation. Two treatment techniques were applied prior to isolation in which $1.4 \%$ phenol was mixed with soil following the method of Nonomura and Hayakawa (1988). However, dry heat at $100^{\circ} \mathrm{C}$ for 1 hour (Nonomura and Ohara, 1969); was used as the second treatment to compare the number of actionbacteria recovered. Untreated soil from each soil type, served as a control.

\section{Isolation of actinobacteria and media used}

Actinobacterial colonies were isolated following the procedure of Mansour et al., (2015), in which the pretreated and the control soil samples were subjected to serial dilutions up to $10^{-4}$ using sterile saline solution. Starch casein medium was used for isolation after being inoculated with $0.5 \mathrm{ml}$ of different diluted soil samples using pour plate technique. Three plates, serving as replica, were used for each dilution per treatment for each soil types. Starch casein medium (SCM) used has the following ingredients $(\mathrm{g} / \mathrm{L})$ : casein powder 0.3 , starch 10.0 , sodium nitrate 2.0 ; sodium chloride 2.0; dipotassium hydrogen phosphate 2.0; magnesium sulfate 0.005 ; calcium carbonate 0.002 ; ferrous sulfate 0.001 ; agar 15.0 ; final $\mathrm{pH} 7.2 \pm 0.2$.The medium was supplemented with antifungal cycloheximide $(50 \mathrm{mg} / \mathrm{L})$. After 7 days of incubation at
$28 \pm 2^{\circ} \mathrm{C}$, colonies exhibiting typical characteristics of actinobacterial morphology were counted and picked up for purification. For isolation of slow growingactinobacteria, plates were kept longer in the incubator and checked regularly for three consecutive weeks. Pure actinobacterial colonies were propagated on SCM for further use.

\section{Screening for antimicrobial activity}

For primary screening of actinobacterial isolates for antimicrobial activity, agar disc overlay bioassay was used (Teresa et al., 1991; Deepika et al., 2011). In this technique, nutrient agar plates were used and inoculated with individual selected pathogenic bacteria and yeast. Discs of actinobacterial cultures (7 days old pure cultures), were removed with a sterilized cork borer and applied on the bacterial seeded plate with the challenged pathogenic microorganisms. Plates were incubated at $37 \pm 2^{\circ} \mathrm{C}$ for 48 hours for tested bacterial pathogens and at $28^{\circ} \mathrm{C} \pm 2$ for yeast. After incubation, plates were examined for inhibition zones developed as a result of the actinobacterial activity. The inhibition zone is represented by a clear hallo zone around the actinobacterial inoculated discs. The active isolates were recorded and then subjected to further screening.

\section{Microbial pathogens used}

The purified actinobacterial isolates were screened for their activity against pathogenic Gram-negative bacteria strains including: Bacillus subtilus, Escherichia coli, Klebsiella pneumonia, Proteus mirabilis, Salmonella typhi, Salmonella enterica, Shigella dysenteriae. Gram positive pathogenic bacterial strains include: Staphylococcus aureus, Streptococcus pyogenes were also tested. Antimicrobial activity of isolated actinobacteria was similarly tested against fungal pathogen of genus Candida albicans. These tested microorganisms were obtained from the American Type Culture Collection (ATCC).

\section{Screening for natural products as secondary meta- bolites}

\section{Production of crude metabolite}

Isolates exhibiting potential antimicrobial activities from primary screening were subjected to submerged state fermentation method for bioactive compound productions. Actinobacterial isolates were inoculated separately into $10 \mathrm{ml}$ of starch casein broth (SCB), final $\mathrm{pH} 7.2 \pm 0.2$, and then incubated at $30^{\circ} \mathrm{C}$ for $7-10$ days. After the inoculation period, the growth media were filtered through a $0.45 \mu \mathrm{m}$ filter and then subjected for screening of natural products.

\section{Antimicrobial activity of crude metabolites}

Exogenous antimicrobial activities of the crude metabolites were tested using disc diffusion method (Deepika et al., 2011). The sterilized discs of Wattman filter paper No.3 were saturated by subsequent loading with specific volume of pure extracted metabolite $(0.2$ $\mathrm{ml}$ ) and gently placed on the surface of nutrient agar separately seeded with selected pathogenic bacteria and yeast. Agar plates were incubated at $37 \pm 2^{\circ} \mathrm{C}$ for 48 to 
72 hours. Inhibition zone around the discs were recorded by measuring their diameters.

\section{Screening for secondary natural occurring com- pounds}

Secondary metabolites produced by each actionbacterial isolate, grown in starch casein broth, were tested for natural produced compounds that include: alkaloids, tannin and phenols.

\section{Alkaloids detection}

Alkaloid-products of all selected actinobacterial isolates were detected by using two different tests: Wagner's and Hager's tests in which brownish or yellowish precipitate was observed following the techniques of Joseph et al. (2013) and Neelima et al., (2011), respectively.

\section{Phenol and Tannin tests}

Phenolic, the most pronounced active metabolite along with tannin compounds were tested, for their existence in the secondary metabolites collected from isolated actinobacteria, using the techniques described by Neelima et al., (2011).

\section{Characterization and identification of most active actinobacterial isolates \\ Morphological characterization}

The most potent isolated actinobacteria were described to generic level using micromorphological, biochemical and physiological tests. For micromorphological characterization, investigation under the light microscope was carried using sterile oblique slide technique (Mansour, 2003). The slides were examined, after being stained with Gram-stain. Spore orientation and their morphological types were recorded.

\section{Culture characterization}

Culture characterization of the isolates was carried out using different culture media: starch casein agar, ISP1, nutrient agar, peptone meat extract, and peptone water. Selected isolates were inoculated aseptically in these media and incubated at $30^{\circ} \mathrm{C}$ for 7 days. The macromorphology includes: colony shape, color of aerial and substrate mycelia, the formation of aerial hyphae and the ability for diffusible pigment production, were recorded for each isolate per medium used.

\section{Physiological and biochemical characterizations}

Some physiological and biochemical characterizations were carried out to identify the behavior of the antimicrobial-active actinobacterial isolates. Among these tests were the abitity to utilise casein, hydrolyse of gelatin; optimal temperature and $\mathrm{pH}$ required for growth; production of some enzymes like catalase and $\alpha$-amylase and ability for nitrate reduction and $\mathrm{H}_{2} \mathrm{~S}$ production. All testes were carried out following the techniques described by Mansour et al. (2015).

\section{Statistical analysis}

The data recorded were statistically analyzed through the SPSS program (version 5.2) for significance differences among the data recorded using ANOVA and the Duncan multiple range test. Data was significantly different at $p \leq 0.05$ level.

\section{RESULTS AND DISCUSSION}

The population of actinobacteria, isolated per soil sample collected from Ngaoundere, was shown to be significantly different in the two selected locations. In meantime, soil pretreatments also recorded significant differences for soil sites and within the soil of the same site (Table 1). Total actinobacterial counts recorded the highest population in compost soil when compared to polluted one. A statistically significant difference $(p \leq 0.05)$ was detected among type of pretreatments in comparison to untreated soil (Table 1).

Pretreated compost soil using dry heat for $1 \mathrm{~h}$ at $120^{\circ} \mathrm{C}$ showed significant less recovered actinobacterial colonies compared to untreated or phenoltreated soil. However, polluted soil showed reverse response after dry heat pretreatment was applied in which the highest count of actinobacterial colonies was recorded. Although the population of the recovered actinobacterial colonies was significantly the highest, no significant differences at $\mathrm{p} \leq 0.05$ level was recorded compared with untreated soil.

Table (1): Total count of actinobacterial colonies represented by colony forming units (CFU/g) in two different soils collected from compost site and vehicle repairing station (polluted with hydrocarbons), Ngaoundere, Cameroon.

\begin{tabular}{lccc}
\hline \hline \multicolumn{3}{c}{ Total count of actinobacteria colonies $\left(\mathbf{1 0}^{\mathbf{2}}\right.$ CFU/g soil $)$} \\
\hline Treatments & Compost soil & Polluted soil & $\begin{array}{l}\boldsymbol{p} \text { - } \\
\text { value }\end{array}$ \\
\hline $\begin{array}{l}\text { Phenol } \\
(\mathbf{1 . 4 \%})\end{array}$ & $1400.0 \pm 45.0^{\mathrm{a}}$ & $6.60 \pm 3.3^{\mathrm{b}}$ & 0.03 \\
$\begin{array}{l}\text { Dry heat } \\
\left(\mathbf{1 0 0} \mathbf{}^{\circ} \mathbf{C}\right)\end{array}$ & $130.0 \pm 8.0^{\mathrm{b}}$ & $160.0 \pm 60.0^{\mathrm{a}}$ & 0.08 \\
$\begin{array}{l}\text { Untreated } \\
(\text { Control })\end{array}$ & $1430.0 \pm 460.0^{\mathrm{a}}$ & $130.0 \pm 80.0^{\mathrm{a}}$ & 0.05 \\
\begin{tabular}{l}
$\boldsymbol{p}$-value \\
\hline \hline
\end{tabular}
\end{tabular}

Data are mean values of triplicate \pm SE. Different letters indicate significant differences at $p \leq 0.05$ level using Duncan Multiple Range Test.

The results also indicate that the compost soil which is rich in organic matter (182 $\mathrm{g} / \mathrm{kg}$ soil) has much population of actinobacteria compared to polluted soil which has the approximate the same organic matter percentage $(200 \mathrm{~g} / \mathrm{kg}$ soil). This contradiction result can be explained by the negative effect of oil hydrocarbons on actinobacterial population. These data are in agreement with results obtained by Saadoun et al., (2008). In their study, they found that microbial populations inhabit the crude petroleum contaminated soils were greatly declined compared to uncontaminated soil. In the meantime, Walter et al. (1991) and Dean-Ross (1990) also recorded a decrease in microbiota of oil contaminant soil and they concluded that the fresh oil spills and/or high levels of contaminants often destroy or inhibit a large sector of the soil microbiota, whereas soils with lesser levels of aged contamination show a greater number and moderate diversity of microorganisms. 


\section{Pharmaceutically active secondary metabolites of newly isolated actinobacteria from two Cameroonian soils}

Based on micromorphological, culture, biochemical and physiological characterizations of actinobacteria isolates, the study revealed that there are seven genera have been recognized in both soil types. Genus Actinomadura and Streptomyces were the most dominant genera (Fig. 1). The compost soil, exhibited higher microbial counts $\left(\sim 1430.0 \log ^{2} \mathrm{CFU} / \mathrm{g}\right)$, and recorded the highest occurrence percentage for genus Streptomyces (47.62 \%) for untreated soil. However, treated soil recorded decline in Streptomyces occurrences which represented by 40 and $25 \%$ for dry heat and phenol pretreatments, respectively (Fig. 1). This recorded data was consistent with results obtained by Hayakawa et al., (2004), where they used phenol treatment to select members of the less abundant than Streptomyces phenotypic-cluster and eliminate other common streptomycete clusters.

Regarding the analysis at the actinobacteria genera level for diversity, the investigated polluted soil revealed to be the less diverse compared to compost soil. In polluted soil, streptomycete and actinomaduraclusters were highly abundant and represented by $92.86 \%$ of the total genera recorded. Moreover, Actinomadura was the most significant occurred genus (57.14 $\%$, Fig. 1). The data recorded may indicate that this genus, in particular soil, is able to resist/metabolize this type of aromatic hydrocarbons and disseminate faster that can mask or prevent the propagation of other rare actinobacteria genera. Therefore, the diversity of actionbacteria in this soil type decreased and recorded less significant in number of genera existed. Such observation was in logicality fits with the admitted rule indicating that soil contaminated with hydrocarbons reduces species richness and diversity (Johnston and Roberts 2009). Generally, our study proved that Streptomyces and Actinomadura are the most dominant actionbacterial genera retrieved from different soil samples (Vijayakumar (2007), Remya and Vijayakumar (2008), Cholarajan, et al. (2013).

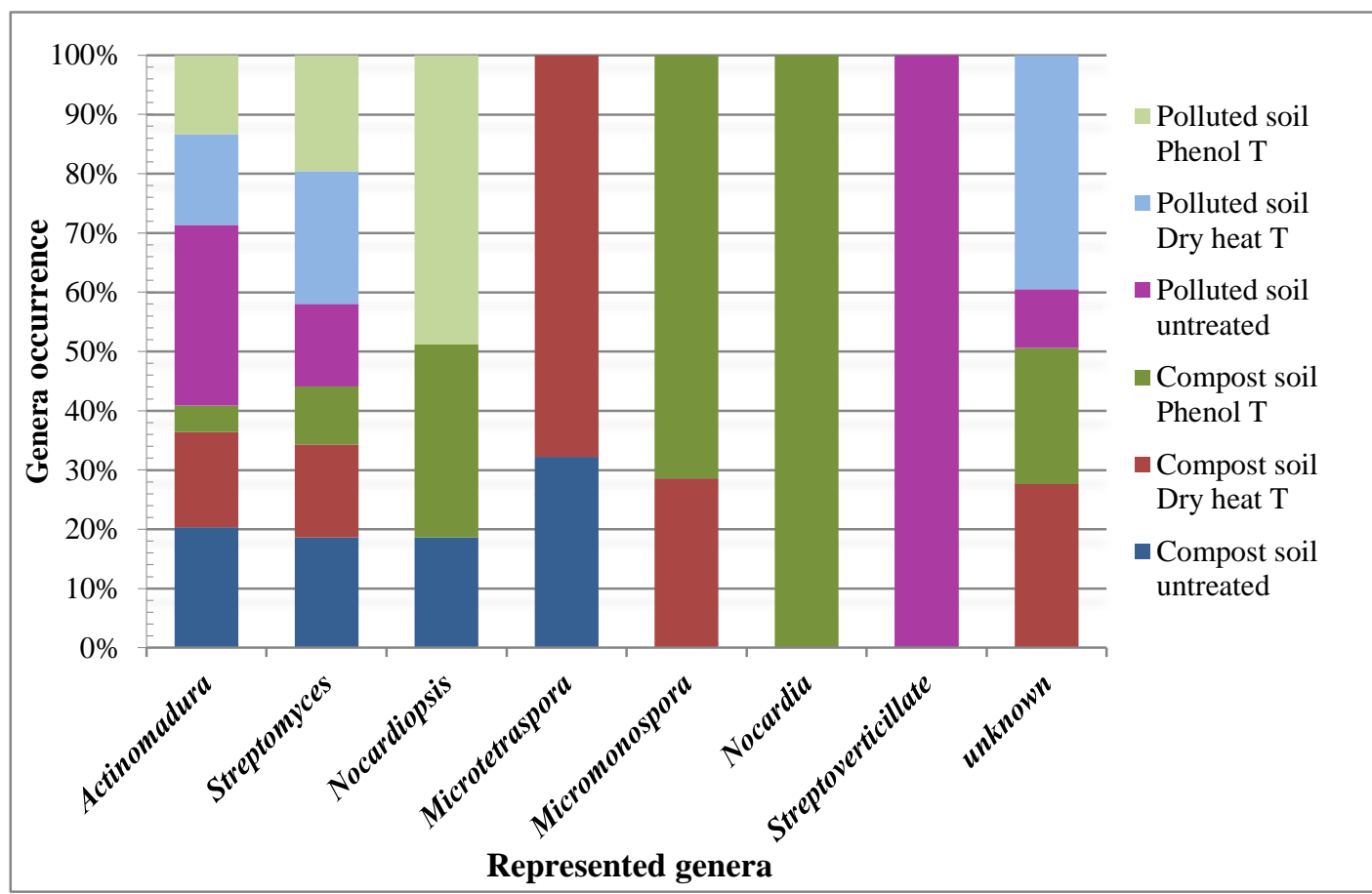

Figure (1): The occurrence of the predominant actinobacterial genera, represented in percentage, in two different Cameroonian soils (compost and polluted soils) subjected to dry heat and phenol treatments.

Our data showed that a total of 82 out of 101 actinobacteria isolates were recovered from two soil samples. Forty-three isolates were retrieved form compost soil and another thirty-nine isolates from polluted soils. Screening for the antagonistic activity of actinobacteria against pathogenic microorganisms (Supplementary S1 and S2) revealed the presence of powerful antimicrobial-producing isolates. As a result of our primary screening, fifty-seven isolates showed antimicrobial activity against one or more tested pathogenic bacteria and yeast. Compost soil isolates showed antimicrobial activity that represented by $62.80 \%$ of the recovered isolates (27 isolates out of forty-three). However, polluted soil showed more active antimicrobial-producers and recorded thirty isolates out of thirty-nine ( $76.92 \%$ of the total isolates) capable to inhibit human bacterial pathogens (Figure 2).

For the secondary screening test, using metabolites, the study revealed that isolates CSU3, CSU5, CSD 50, PSU28, PSU30 and PSP3, had a wide range of antimicrobial activities compared to the rest of active isolates. CSU5 isolate, from compost-untreated soil, was the highest and recorded activity against all tested pathogens followed by PSP3 isolate, from polluted phenol treated soil, which inhibit eight pathogens. In 


\section{Toukam et al}

meantime, CSU5 and CSD50 showed strong inhibition effect against Klebsiella pneumoniae, Staphylococcus aureus, Escherichia coli, Streptococcus pyogenes and Candida albicans (Figure 2). Some other isolates also showed powerful inhibitory effect against specific pathogen; among these isolates were CSU26 and CSP39 against Shigella dysentery and Staphylococcus aureus, respectively. Isolates PSU36 and PSP14 also showed strong inhibitory effect against Staphylococcus aureus. The investigation for antimicrobial producingactinobacteria in newly explored sources, Cameroonian soil in our case, proves the importance of these organisms to compensate the emergence of multidrugresistant bacteria. Our results are in agreement with many studies done to explore the antimicrobial activities of actinobacteria inhabitant different sources (Elbendary et al., 2018; Learn-Han et al., 2014; Kumar et al., 2013; Kekuda et al., 2010 and Khanna et al., 2011).

Evaluation of antimicrobial activity of actionbacterial isolates, recovered from two selected soil, showed that compost soil had more activity against Candida albicans and Gram-negative bacteria; Salmonella enteric and Shigella dysentery. However, polluted soil had higher active-isolates and was able to inhibit both
Gram-native and positive pathogens; E.coli and Proteus mirabilis for Gram-negative and Staphylococcus aureus and Streptococcus pyogenes for Grampositive bacteria (Fig. 2). The strain Streptococcus pyogenes, S. aureus and E.coli, in sequence, were the most sensitive pathogens to the metabolites produced by actinobacteria isolates from both soil-types. Similar result was obtained by Porsani et al., (2013). In their results, $S$. aureus was the most sensitive pathogen to their tested isolates. In the same means, Vijayakumar et al., (2008) tested the antimicrobial activity pattern of the marine actinobacteria against various human pathogenic bacteria and fungi, and reported that the inhibitory effect was varied depends on the active component produced by actinobacteria isolates.

In general, our soil is rich with potent isolates for highly danger human pathogens which considered one of the richest sources of new bioactive compounds due to the diversity of metabolically complex microorganisms inhabited. This finding is in agreement with data obtained by Usha et al., (2011). In their study they showed that actinobacteria present in soil surface were represented an attractive supply for isolation of new microorganisms for production of powerful secondary bioactive metabolites.



Figure (2): Number of antimicrobial-producing actinobacteria isolated from two different Cameroonian soil collected from compost and polluted soils, Ngaoundere, Cameroon.

The investigated actinobacteria isolates that showed very low activity were represented by $1.72 \%$, of the active isolates against Salmonella typhi and S.entrica. In meantime, for Klebsiella pneumonia, only $8.62 \%$ of Cameroonian active isolates were able to inhibit and recorded by the most potent isolated from compost soil (CSU3, CSU5 and CSU 50, Figure 3) and two from polluted soil (PSP3 and PSU24). As far as the polluted soil is concerned, whereas isolates had no activity against Salmonella typhi, only isolate PSP3 showed an activity against Salmonella enteric.

Examination for more natural products can be secreted by actinobacteria in the cultural medium, like phenolic, alkaloid and tannin compounds was run with all isolated actinobacteria. The study revealed that all isolates were not able to produce phenolic compounds (Supplementary S3 and S4); however, most of the 


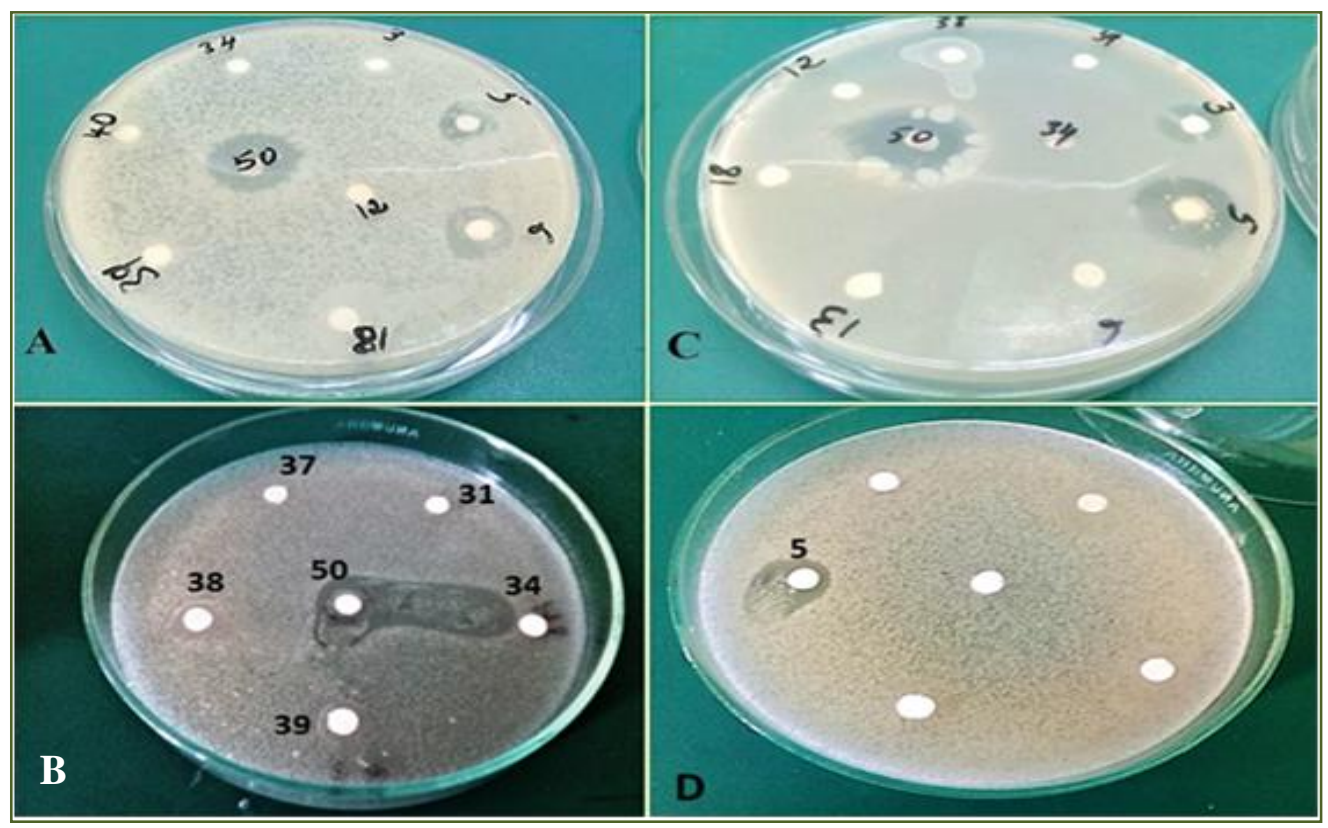

Figure (3): Antimicrobial activity of actinobacterial isolates, isolated from Cameroonian soil, against human pathogens. A, B, C and D are plates seeded with pathogenic microorganisms; Candida albicans, Bacillus subtilus, Staphylococcus aureus and Salmonella enteric, respectively. Active organisms:50, Micromonospora sp.(CSU 50); 5, Nocardiopsis (CSU5) and 3, Microtetraspora (CSU3).

actinonobacteria isolates could produce alkaloid and tannin-compounds as secondary metabolites, particularly for actinobacteria isolated from polluted soil. Further study is in need to analyze these compounds and have more details for their structures. Higher actinobacteria-producing alkaloids or tannin compounnds, for the first time to be detected for microorganism, was significantly proved that the stress of pollution may play a role to upgrading such molecules that help the microbes to struggle for their existence. In agreement with our thought, some studies have been done on medicinal plants and proved that the stress, including growing under water deficiency, high salinity and conditions, could enhance much higher concentrations of relevant natural products compared with identical plants of the same species cultivated under normal conditions (Li et al., 2011; Ma et al., 2014, Gengmao, 2015 and Yang et al., (2018).

The most potent isolates were studied in details and based on their characterizations they found to be belonging to genera: Microtetraspora, Nocardiopsis Micromonospora and Streptomyces for CSU3, CSU5, CSU50, PSU28 and PSU30, respectively (Figure 4 and $5)$. Their spore morphology were varied and showed straight to curved of short chain of spores (CSU3), fragmented spores where fragmentation observed only in aerial mycelium (CSU5), formation of single spore on short/long stalk that exist in solitary or in aggregation (CDU 50). However, all the isolated from polluted soil were belong to genus Streptomyces and their spore morphology were ranged from rectiflexuous spore chain/Spiral (PSU30), looped to open loop spiral (PSP3 and PSU28, respectively, Figure 4 and 5).The growth of these active isolates on different casein medium compared to other media used and the culture media (Table 2) showed good growth on starch color of their aerial and substrate mycelia showed variation based on the different media used with ability for production of diffusible pigment that ranged from brown to red. The occurrence for more potent isolates belonging to the genus Streptomyces confirm the conclusion reported Cholarajan et al., (2013) who described the Streptomyces phenotype-groups are promising for novel antimicrobial production.

For physiological characterization, all the potent isolates were able to produce $\alpha$-amylase and catalase (Table 3). They exhibited a strong $\alpha$-amylase production, except for isolate of genus Streptomyces $s p$ (PSU28), which recorded a weak activity. The production of catalase enzyme ranged from moderate to weak for all tested isolates (Table 3). For gelatin hydrolysis, none of the isolates were able to hydrolyze it. Ability for $\mathrm{H}_{2} \mathrm{~S}$ production was also carried out and our data recorded positive ability for all isolates, but with weak activity. Potent isolates were also able to reduce nitrate, with a strong activity, except for Micromonospora sp. (CSD50). Melanin pigment was produced by most of the isolates and reported a range of activity from negative (Micromonospora sp., CSD50) to weak activity for Microtetraspora $s p$ and Nocardiopsis sp. For all Streptomyces sp. (PSU28, PSU30 and PSP3) moderate melanin production was recorded (Table 3).

\section{CONCLUSION}

This is the first report for actinobacteria isolated from Cameroonian soil. Soil actinobacterial community was mainly controlled by exposure of soil sam- 
Toukam et al

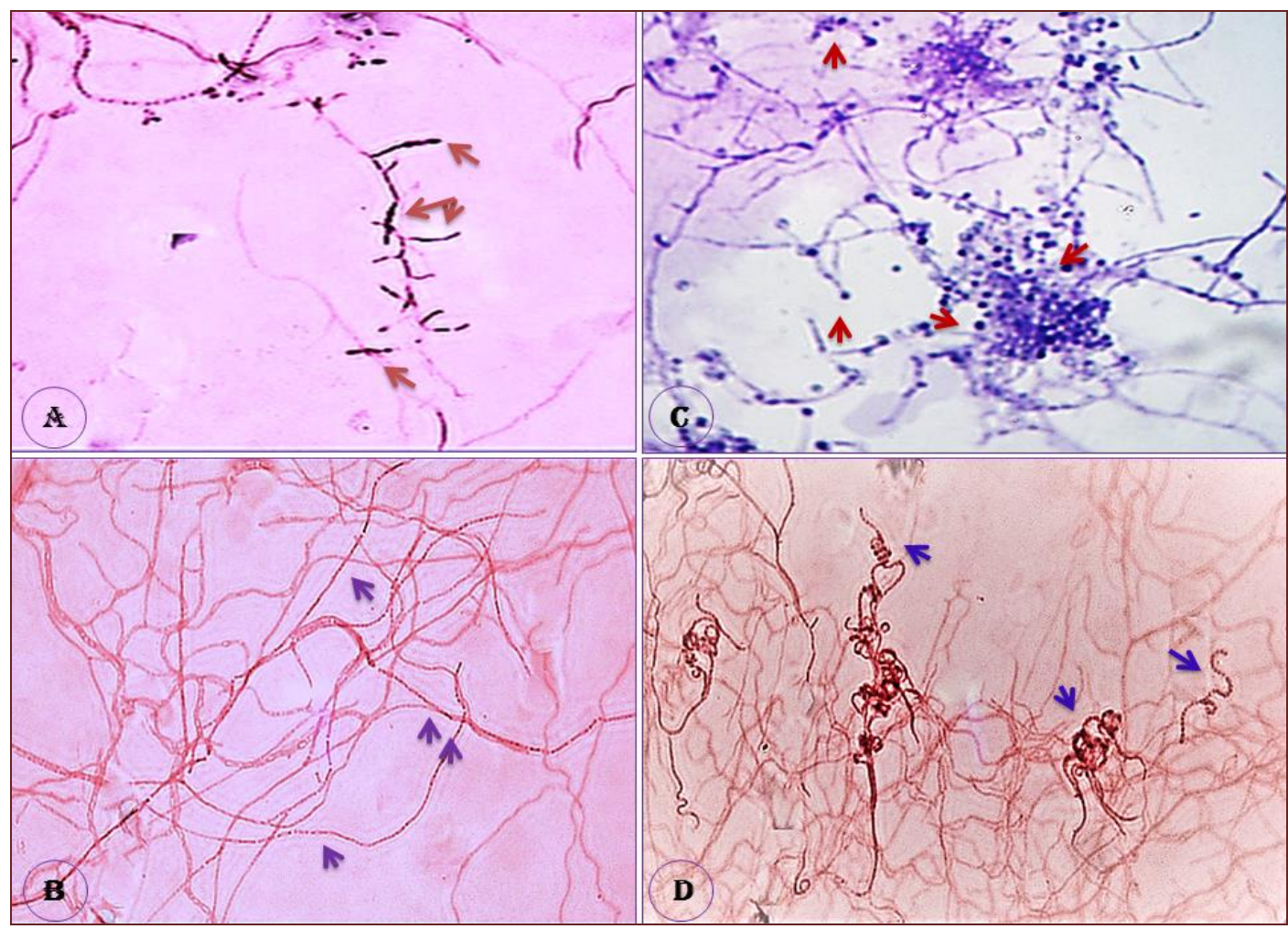

Figure (4): Micromorphology of the potent antimicrobial-producing isolates. A, Microtetraspore sp. (CSU3), showing spore chain on aerial mycelium; B, Nocardiopsis sp. (CSU5), showing fragmented aerial mycelium; C, Micromonospora sp. (CSU 50) showing cluster of single spore born on short stalk substrate mycelium; D, Streptomyces sp. (PSU30), showing spiral of long chain of arthrospores born on aerial hyphae (arrows).

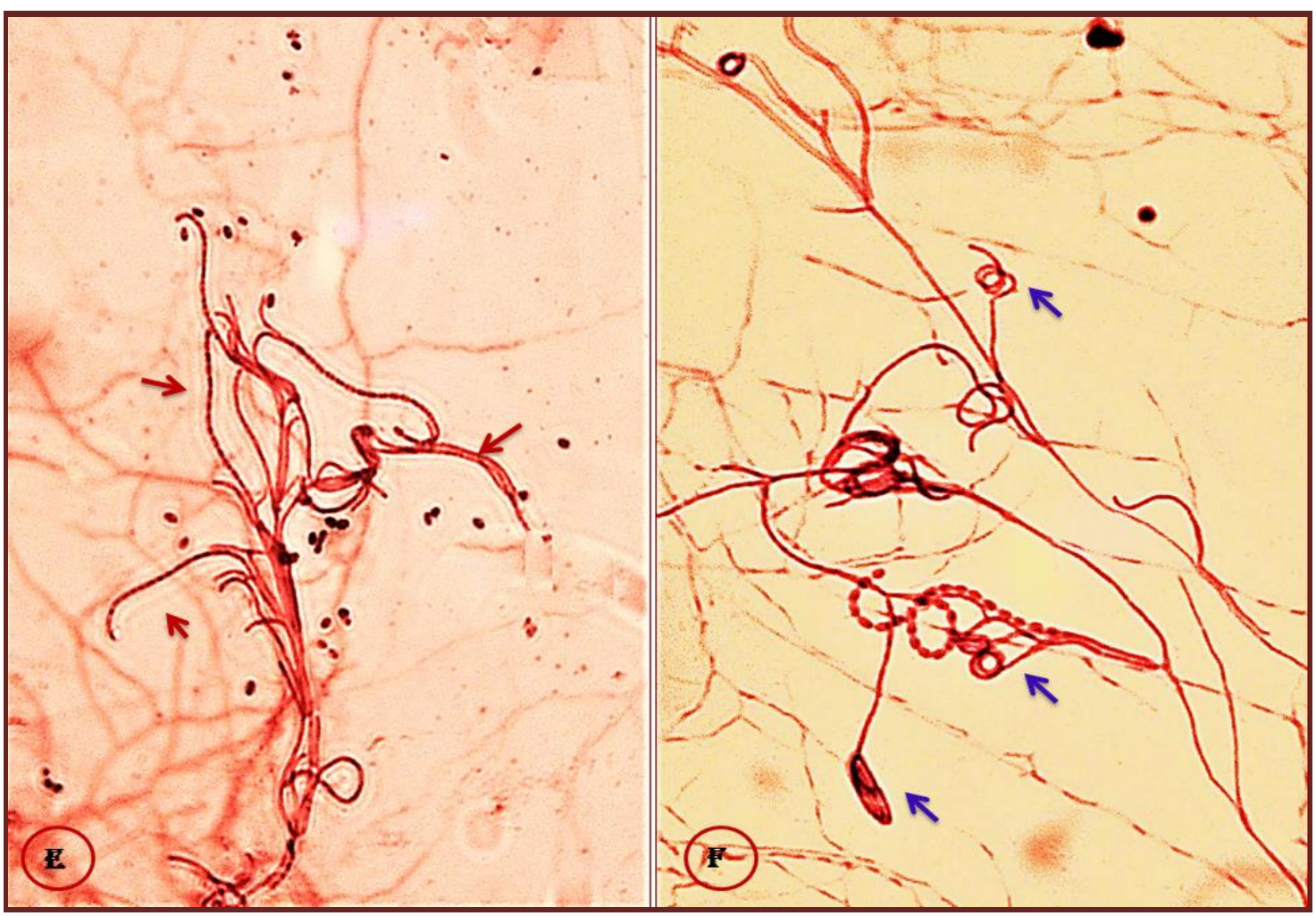

Figure (5): Micromorphology of the potent antimicrobial-producing isolates. E and F, Streptomyces sp. (isolates PSP3 and PSU28), are showing different shapes of long chain of arthrospores born on aerial mycelium. 
Pharmaceutically active secondary metabolites of newly isolated actinobacteria from two Cameroonian soils

Table 2: Cultural characteristics of the potent antimicrobial producing-actinobacterial isolates retrieved from two Cameroonian soils, compost and polluted soils.

\begin{tabular}{|c|c|c|c|c|c|c|c|c|c|c|c|c|c|c|c|c|c|c|c|c|}
\hline \multirow{2}{*}{$\begin{array}{l}\text { Isolate } \\
\text { code }\end{array}$} & \multicolumn{4}{|c|}{ Starch casein agar } & \multicolumn{4}{|c|}{ Nutrient agar } & \multicolumn{4}{|c|}{ Peptone water } & \multicolumn{5}{|c|}{ Peptone meat extract } & \multicolumn{3}{|l|}{ ISP1 } \\
\hline & GR & $\mathrm{AM}$ & SM & DP & GR & $\mathrm{AM}$ & SM & DP & GR & $\mathrm{AM}$ & S M & DP & GR & $\mathrm{AM}$ & SM & DP & GR & $\mathrm{AM}$ & SM & DP \\
\hline CSU3 & +++ & $\begin{array}{l}\text { Faint } \\
\text { gray }\end{array}$ & Pink & - & ++ & - & Cream & - & +++ & White & Cream & Brown & ++ & No & Cream & - & ++ & Gray & Cream & Red \\
\hline CSU5 & +++ & $\begin{array}{l}\text { Whitis } \\
\text { h gray }\end{array}$ & Cream & - & ++ & Beige & Cream & - & ++ & $\begin{array}{l}\text { Faint } \\
\text { gray }\end{array}$ & Cream & Brown & +++ & Black & Cream & Red & + & $\begin{array}{l}\text { scanty } \\
\text { white }\end{array}$ & Cream & - \\
\hline CSD50 & +++ & - & Brown & Brown & ++ & - & Cream & Rose & ++ & - & Brown & Brown & + & No & Brown & - & ++ & Black & $\begin{array}{l}\text { Rdish } \\
\text { Brown }\end{array}$ & Brown \\
\hline PSU28 & +++ & Gray & Cream & Brown & + & Gray & Cream & - & +++ & $\begin{array}{l}\text { Whitish } \\
\text { gray }\end{array}$ & Cream & - & +++ & White & Cream & - & +++ & White & Cream & - \\
\hline PSU30 & +++ & $\begin{array}{l}\text { Dark } \\
\text { gray }\end{array}$ & Cream & - & + & $\begin{array}{l}\text { Whitis } \\
\text { h gray }\end{array}$ & Cream & - & ++ & White & Cream & - & ++ & Gray & Cream & - & +++ & Gray & Cream & - \\
\hline
\end{tabular}

Table 3: Physiological and biochemical characteristics of the potent actinobacterial isolates, have antimicrobial activity, isolated from two Cameroonian soils.

\begin{tabular}{|c|c|c|c|c|c|c|c|c|}
\hline \multirow{2}{*}{ Actinobacteria genera } & \multicolumn{2}{|c|}{$\begin{array}{l}\text { Growth at different } \\
\text { Temperature }\left({ }^{\circ} \mathrm{C}\right)\end{array}$} & \multirow{2}{*}{ Casein utilization } & \multirow{2}{*}{$\alpha$-amylase } & \multirow{2}{*}{ Catalase } & \multirow{2}{*}{$\mathrm{H}_{2} \mathrm{~S}$ production } & \multirow{2}{*}{ Melanin production } & \multirow{2}{*}{ Nitrate reduction } \\
\hline & 28 & 40 & & & & & & \\
\hline Microtetraspora sp. & +++ & ++ & + & +++ & + & \pm & \pm & ++++ \\
\hline Nocardiopsis sp. & ++ & +++ & ++ & +++ & + & \pm & \pm & +++ \\
\hline Micromonospora sp. & +++ & + & ++ & +++ & ++ & + & - & \pm \\
\hline Streptomyces sp. & +++ & +++ & ++ & \pm & + & \pm & ++ & +++ \\
\hline Streptomyces sp. & +++ & + & +++ & +++ & + & + & ++ & +++ \\
\hline Streptomyces sp. & +++ & +++ & +++ & ++ & + & + & ++ & + \\
\hline
\end{tabular}

+, weak; ++, moderate growth; +++, good growth. 
ples to different treatments which recorded decline in their count. Hydrocarbon-polluted soil collected from vehicles repairing station, recoded less diversity in genera recovered. The potential of the isolated actinobacteria for production of antimicrobial and natural compounds (alkaloid or tannin) prove that these are promising isolates for pharmaceutical purposes. Their powerful capability to inhibit Candida albicans, Salmonella, Shigella species and E.coli are considered as candidate for further study to isolate the active component for industrial production and commercial uses. For other antibiotic-actinobacterial producers, may be promising for biotechnological applications especially for the common dangerous pathogens like Salmonella, Shigella species and E.coli, after being analyzed for the active component (s). Therefore, more study is needed to find the optimal condition for maximum antimicrobial metabolite productions for such pathogens.

\section{ACKNOWLEDGMENT}

The authors are hereby acknowledging the Microbiology Laboratory of the Department of Botany, Suez Canal University, Ismailia, Egypt, for providing all the necessary facilities that enabled the achievement of all work done.

\section{REFERENCES}

CHAUDHARY H.S., J. YADAV, A.R. SHRIVASTAVA, S. SINGH, A.K. SINGH AND N. GOPALAN. 2013. Antibacterial Activity of Actinomycetes Isolated from Different Soil Samples of Sheopur (A city of Central India). Journal of Advanced Pharmaeutical Technology and Research, 4: 118-23.

CHOLARAJAN, A, AND R. VIJAYAKUMAR. 2013. Isolation, Identification, Characterization And Screening of Antibiotic-Producing Actinobacteria From The Crop Fields of Thanjavur District, Tamilnadu, India. Int J Recent Sci Res; 4:55-60. Conditions. Journal of Fermentation and Bioengineering, 83: 523-528.

DEAN-ROSS, D. 1989.Bacterial Abundance and Activity in Hazardous Waste-Contaminated Soil DEEPIKA, S, K, TALWINDER, B.S. CHADHA, K. M. RAJESH. 2011. Antimicrobial Activity of Actinomycetes Against Multidrug Resistant Staphylococcus aureus, E. coli and Various Other Pathogens Tropical Journal of Pharmaceutical Research. 10 (6): 801-808.

ELBENDARY, A.A, A.M.HESSAIN, M.D ELHARIRI', A.SEIDA AHMED , M.MOUSSA IHAB , S.MUBARAK AYMAN, A.KABLI SALEH , A.HEMEG HASSAN , AND. K. JAKEE JAKEEN. 2018. Isolation of Antimicrobial Producing Actinobacteria From Soil Samples. Saudi Journal of Biological Sciences, Vol. 25, (1): 44-46.

GENGMAO, Z., H. YU, S. XING, L. SHIHUI, S. QUANMEIAND, S. XING, C. WANG. 2015. Salinity stress increases secondary metabolites and enzyme activity in safflower. Industrial Crops and
Products, 64(1):175-181.DOI: 10.1016/j. indcrop. 2014.10.058

HAYAKAWA, M., Y. YOSHIDA, AND Y. IIMURA 2004. Selective Isolation of Bioactive Soil Actinomycetes Belonging to The Streptomyces Violaceusniger Phenotypic Cluster. the Society for Applied Microbiology, Journal of Applied Microbiology, 96, 973-981, Doi:10.1111/J.13652672.2004.02230.X.

JOHNSTON, E. L., AND ROBERTS, D. A. 2009. Contaminants Reduce the Richness and Evenness of Marine Communities: A review and MetaAnalysis. Environ. Pollut. 157, 1745-1752.doi: 10.1016/j.envpol.2009.02.017

JOSEPH, B.S., P.H. KUMBHARE, AND M.C. KALE. 2013. Preliminary Phytochemical Screening of Selected Medicinal Plants. International Research Journal of Science \& Engineering.; 1(2): 55-62.

KEKUDA, T.R.P., K. S. SHOBH, R.ONKARAPPA. 2010. Fascinating Diversity and Potent Biological Activities of Actinomycetes Metabolites. J. Pharm. Res. 3: 250-256.

KHANNA, M., R. SOLANKI AND R. LAL, 2011. Selective isolation of rare actinomycetes producing novel antimicrobial compounds. Int. J. Adv. Biotechnol. Res., 2: 357-375.

KUMAR, V., G.S. BISHT, AND O. GUSAIN. 2013.Terrestrial Actinomycetes From Diverse Locations of Uttarakhnad, India: Isolation and Screening for Their Antibacterial Activity. Iranian Journal Of Microbiology, 5(3), 299-308.

LACEY, J. 1997. Actinomycetes in Composts. Annals of Agricultural and Environmental Medecine, 4: 113-121.

LEARN-HAN, LEE, ZAINAL, NURULLHUDDA, AND AZMAN, ADZZIE-SHAZLEEN. 2014. Diversity and Antimicrobial Activities of Actinobacteria Isolated From Tropical Mangrove Sediments in Malaysia. the Scientific World Journal, vol. Article ID 698178, 14. https://doi.org/10.1155/2014/698178.

LI, W.D., J.L HOU,., W.Q. WANG, X.M TANG, C.L LIU,. AND D. XING, 2011. Effect of Water Deficit on Biomass Production and Accumulation of Secondary Metabolites in Roots of Glycyrrhiza Uralensis. Russian Journal of Plant Physiology, 58, 538-542.

MA, D., D. SUN, C. WANG, Y. LI AND T. GUO. 2014. Expression of Flavonoid Biosynthesis Genes and Accumulation of Flavonoid in Wheat Leaves in Response to Drought Stress, Plant Physiology and Biochemistry, 80: 60-66.

MANSOUR S.R. AND I. SAMAR. 2010. Chitinolytic Activity of Actinomycetes From Egyptian Soil and Their Potential in Biocontrol, Role of Biocontrol Agents for Disease Management in Ustainable Agriculture, 301-310.

MANSOUR, S.R. 2003. The Occurrence and Distribution of soil Actinomycetes in Saint Catherine Area, South Sinai, Egypt. Pakistan Journal of Biological Science, 6: 721-728.

MANSOUR, S.R., A.M.ABDEL-AZEEM, AND S.S.S.ABODERAZ. 2015. A New Record of 
Actinobacteria Isolated From Soil in Jerusalem And their Enzymatic Potential [V1, Ref Status, Http://F1000r.Es/2p5] F1000 Research, 4:11.

NEELIMA, N., N.G.DEVIDAS, M. SUDHAKAR, V.JADHAVK. 2011. A Preliminary Phytochemical Investigation on the Leaves of Solanum xanthocarpum. International Journal of Research in Ayurveda and Pharmacy, 2: 845-850.

NEWMAN, D.J., G.M. CRAGG, K.M. SNADER. 2003.Natural Products As Sources of New Drugs Over the Period 1981-2002. Journal of Natural Products, 66:1022-37.

NONOMURA, H. \& M. HAYAKAWA. 1988. New methods for the selective isolation of soil actinomycetes. In Biology of Actinomycetes ' 88 ed. Okami, Y., Beppu, T. and Ogawara, H. pp. 288293. Tokyo: Japan Scientific Societies Press.

NONOMURA, H., Y.OHARA. 1969. Distribution of Actinomycetes in Soil. VI. A Culture Method Effective for both Preferential Isolation and Enumeration of Microbispora and Streptosporangium strains in Soil (part 1). Jounal of Fermention Technology, 47: 463-469.

OVERBYE, K.M., J.F. BARRETT. 2005.Antibiotics: Where Did We Go Wrong? Drug Discov. Today, 10: 45-52.

PORSANI, M. J., B. URSIN, M. G. SILVA, AND P. E. M. . MELO, 2013, Dip-adaptive singular-value decomposition filtering for seismic reflection enhancement: Geophysical Prospect-ing, 61, 42-52.

REMYA, M, R. VIJAYAKUMAR. 2008. Isolation and Characterization of Marine Antagonistic Actinomycetes from West Coast of India. Facta Universitatis; 15: 13-19.

SAADOUN, I., M. J. MOHAMMAD, K.M. HAMEED, AND M. SHAWAQFAH. 2008. Microbial Populations of Crude Oil Spill Polluted Soils at the Jordan-Iraq Desert (The Badia Region). Brazilian Journal of Microbiology, 39(3), 453-456. Http://Doi.Org/10.1590/S151783822008000300008

SAHAYA, MARY R., AND D. MANORAMA. 2012. Biocontrol Potential of Selected Actinomycete and its Metabolites Against Rhizoctonia solani. Indian Journal of Natural Sciences, 3: 965-972.

TAMURA, S., Y. PARK, M.TORIYAMA, AND M.OKABE.1997. Change of Mycelial Morphology in Tyrosin Production by Batch Culture of Streptomyces Fradiae Under Various Shear Conditions. Journal of Fermentation and Bioengineering, 83: 523-528.

TERESA, H., P.NEIL , MICHAEEL B. 1991. Postive Selection of Antibiotic-Producing Soil Isolates. Journal of General Microbiology, 137: 2321-2329.

USHA, Y., KOPPULA, S., VISHNUVARDHAN, Z. 2011. Bioactive Metabolites From Marine Sediments (Streptomyces species) of Three Coastal Areas. Drug Invention Today, 2: 114-117.

VIJAYAKUMAR R, C. MUTHUKUMAR , N. THAJUDDIN , A.PANNEERSELAVAM. 2007. Studies on the Diversity of Actinomycetes in the Palk Strait Region of Bay of Bengal, India. Actinomycetologica; 21: 59-65.

VIJAYAKUMAR R, C. MUTHUKUMAR, N. THAJUDDIN, PANNEERSELAVAM. 2008. Studies on the diversity of actinomycetes in the Palk Strait region of Bay of Bengal, India. Actinomycetologica; 21:59-65.

WALTER U., M. BEYER, J. KLEIN, H.J. REHM 1991. Degradation of Pyren by Rhodococcus sp.Appl. Microbiol. Biotechnol. 34: 671-676.

YANG, L., K-S. WEN, X. RUAN, Y-X. ZHAO, F.WEI, AND Q. WANG. 2018. Response of Plant Secondary Metabolites to Environmental Factors. Molecules, 23: 762: 1-26 doi:10.3390/Molecules 23040762 . 


\section{Toukam et al}

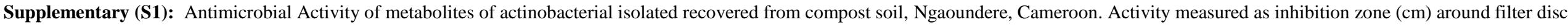
loaded with $200 \mu \mathrm{l}$ of the metabolite of each isolate tested. Data are mean of three plates as replica.

\begin{tabular}{|c|c|c|c|c|c|c|c|c|c|c|c|c|c|c|c|c|c|c|c|c|c|}
\hline \multirow{2}{*}{$\begin{array}{l}\text { Isolate } \\
\text { code }\end{array}$} & \multicolumn{10}{|c|}{ Pathogenic strain used $\dagger$} & \multirow{2}{*}{$\begin{array}{l}\text { Isolate } \\
\text { code }\end{array}$} & \multicolumn{10}{|c|}{ Pathogenic strain used } \\
\hline & 1 & 2 & 3 & 4 & 5 & 6 & 7 & 8 & 9 & 10 & & 1 & 2 & 3 & 4 & 5 & 6 & 7 & 8 & 9 & 10 \\
\hline CSU3 & 1.5 & 0.7 & 1.1 & 1.3 & - & - & - & - & 2 & 1.3 & CSP22 & - & - & - & - & - & - & - & - & - & - \\
\hline CSU4 & - & - & - & - & - & - & - & - & - & - & CSP30 & - & 0.8 & - & - & - & - & - & - & - & - \\
\hline CSU5 & 2 & 1.5 & 1.75 & 2.4 & 1.6 & 2 & 1.8 & 2 & 2.3 & 2 & CSP31 & - & - & - & - & - & 1.5 & - & - & - & - \\
\hline CSU6 & 1.6 & 1.6 & 2 & - & - & - & - & - & - & 2.2 & CSP34 & - & - & - & - & - & - & - & - & - & - \\
\hline CSU7 & 1.6 & 1.6 & 2 & - & - & - & - & - & - & 2.2 & CSP37 & - & - & 1 & - & - & - & - & - & - & - \\
\hline CSU8 & - & - & - & - & - & - & - & - & - & 1.9 & CSP38 & 1.2 & 1.6 & - & - & - & 1.3 & - & - & 4 & - \\
\hline CSU9 & - & - & - & - & - & - & - & - & - & - & CSP39 & - & - & 0.8 & - & - & - & - & - & 2.8 & - \\
\hline CSU10 & - & - & - & - & - & - & - & - & - & 1.2 & CSP40 & - & 0.7 & - & - & - & - & - & - & - & - \\
\hline CSU12 & - & - & - & - & - & - & - & - & - & - & CSP41 & - & 1 & - & - & - & - & - & - & - & - \\
\hline CSU13 & 1.4 & 1 & 1.2 & - & - & - & - & - & - & - & CSP43 & - & - & - & - & - & - & - & 1.1 & - & - \\
\hline CSU15 & - & - & - & - & - & - & - & - & 0.9 & - & CSP44 & - & - & - & - & - & 0.6 & - & - & - & - \\
\hline CSU16 & 1.3 & - & - & - & - & - & - & 1 & - & - & CSD2 & - & - & - & - & - & - & - & - & - & 1.2 \\
\hline CSU17 & - & - & - & - & - & - & - & - & - & - & CSD47 & - & - & - & - & - & - & - & - & 1.3 & - \\
\hline CSU18 & - & - & - & - & - & - & - & - & - & - & CSD48 & - & - & - & - & 1.5 & - & - & - & - & 1.5 \\
\hline CSU19 & 0.8 & - & 0.8 & - & - & - & - & 1.6 & 0.8 & - & CSD49 & - & - & - & - & - & - & - & - & - & 1.7 \\
\hline CSU21 & 0.7 & - & - & - & - & - & - & - & - & - & CSD50 & 2.3 & 3.3 & 3 & 2 & - & 2 & - & - & 3 & 3 \\
\hline CSU23 & - & - & - & - & - & - & - & - & - & - & CSD51 & - & - & - & - & - & - & - & - & - & - \\
\hline CSU24 & - & - & - & - & - & - & - & - & - & - & CSD52 & - & - & - & - & - & - & - & - & - & - \\
\hline CSU26 & 1.5 & - & - & - & - & - & - & 2.5 & - & - & CSP23 & - & - & - & - & - & - & - & - & - & - \\
\hline CSU27 & - & - & - & - & - & - & - & - & - & - & CSD53 & - & - & - & - & - & - & - & - & - & - \\
\hline CSU29 & - & - & - & - & - & - & - & 1 & - & - & CSD54 & - & - & - & - & - & - & - & - & - & - \\
\hline CSP1 & - & - & - & - & - & - & - & - & - & - & & & & & & & & & & & \\
\hline
\end{tabular}

$\dagger 1$, B.subtilus; 2,C.albicans; 3, E.coli; 4, K.pneumonia; 5, P.mirabilis, 6, Salmonella enteric; 7, Salmonella.typhi; 8, Shigella dysentery, 9, S.aureus, 10, Streptococcus pyogenes. 
Supplementary (S2): Antimicrobial Activity of metabolites of actinobacterial isolates recovered from polluted soil, Ngaoundere, Cameroon. Activity measured as iinhibition zone (cm) around filter disc loaded with $200 \mu \mathrm{l}$ of the metabolite of each isolate tested. Data are mean of three plates as replica.

\begin{tabular}{|c|c|c|c|c|c|c|c|c|c|c|c|c|c|c|c|c|c|c|c|c|c|}
\hline \multirow{2}{*}{$\begin{array}{l}\text { Isolate } \\
\text { code }\end{array}$} & \multicolumn{10}{|c|}{ Pathogenic strain used $\dagger$} & \multirow{2}{*}{$\begin{array}{c}\text { Isolate } \\
\text { code }\end{array}$} & \multicolumn{10}{|c|}{ Pathogenic strain used } \\
\hline & 1 & 2 & 3 & 4 & 5 & 6 & 7 & 8 & 9 & 10 & & 1 & 2 & 3 & 4 & 5 & 6 & 7 & 8 & 9 & 10 \\
\hline PSU1 & - & - & 1.5 & - & - & - & - & - & - & - & PSU39 & - & - & - & - & - & - & - & - & - & 1.8 \\
\hline PSU2 & - & - & - & - & - & - & - & - & - & - & PSU42 & - & - & - & - & - & - & - & - & - & 1.9 \\
\hline PSU4 & - & - & - & - & - & - & - & - & - & - & PSU43 & - & - & - & - & - & - & - & - & - & - \\
\hline PSU5 & - & - & - & - & - & - & - & - & - & 2 & PSU44 & 0.8 & - & - & - & - & - & - & - & - & 2.2 \\
\hline PSU7 & - & - & - & - & - & - & - & - & 2.3 & 1.5 & PSU45 & - & - & - & - & - & - & - & - & - & 2 \\
\hline PSU8 & - & - & - & - & - & - & - & - & - & 2 & PSU46 & 1.5 & - & 1.2 & - & - & - & - & - & - & - \\
\hline PSU9 & - & - & - & - & 1.3 & - & - & - & - & - & PSP3 & 1.1 & 1.5 & 1.2 & 1.3 & 1.4 & 1.3 & - & - & 1.5 & 1.5 \\
\hline PSU13 & - & - & - & - & 1.4 & - & - & - & - & 1.3 & PSP14 & - & - & 1.5 & - & - & - & - & - & 2.9 & 1.4 \\
\hline PSU18 & 1.2 & - & - & - & - & - & - & - & - & - & PSP19 & - & - & - & - & 1.3 & - & - & 2.3 & 2 & 1.5 \\
\hline PSU22 & - & - & - & - & - & - & - & - & 2 & - & PSP26 & 0.7 & - & 1.1 & - & - & - & - & - & - & 1.5 \\
\hline PSU24 & - & - & 1.6 & 0.8 & 1.2 & - & - & - & 2.2 & 1.3 & PSD20 & - & - & & - & - & - & - & - & - & 1.7 \\
\hline PSU27 & - & 1.8 & - & - & - & - & - & - & 1.5 & 2.2 & PSD21 & - & - & 1.8 & - & - & - & - & - & - & - \\
\hline PSU28 & 1.3 & 1 & 2 & - & - & - & - & - & 2.7 & 1.9 & PSD23 & - & 1.6 & - & - & 1.1 & - & - & - & 2.3 & 2 \\
\hline PSU30 & 1.2 & - & 1.6 & - & - & - & - & 1. & 3 & 1.7 & PSD25 & - & - & - & - & - & - & - & - & - & - \\
\hline PSU33 & 0.8 & - & - & - & - & - & - & - & - & - & PSD31 & 1.7 & - & 1.4 & - & - & - & - & 1 & - & 2 \\
\hline PSU34 & - & - & - & - & - & - & - & - & - & - & PSD32 & - & - & - & - & - & - & - & - & 2 & - \\
\hline PSU35 & - & - & 2 & - & - & - & - & - & - & 2.2 & PSD47 & - & - & - & - & - & - & - & - & - & 1.5 \\
\hline PSU36 & 1.2 & - & - & - & - & - & - & - & 2.6 & - & & & & & & & & & & & \\
\hline PSU37 & - & - & - & - & - & - & - & - & - & - & & & & & & & & & & & \\
\hline PSU38 & - & - & - & - & - & - & - & - & - & - & & & & & & & & & & & \\
\hline
\end{tabular}

$\dagger 1$ B.subtilus; 2,C.albicans; 3, E.coli; 4, K.pneumonia; 5, P.mirabilis, 6, Salmonella enteric; 7, Salmonella.typhi; 8, Shigella dysentery, 9, S.aureus, 10, Streptococcus pyogenes. 


\section{Toukam et al}

Supplementary S3 Screening for natural products (phenolic compounds, tannin and alkaloids) in the crude metabolites of actinobacterial isolates recovered from compost soil collected from Ngaoundere, Cameroon.

\begin{tabular}{|c|c|c|c|c|c|c|c|c|c|c|c|c|c|c|c|}
\hline \multirow{2}{*}{$\begin{array}{l}\text { Isolates } \\
\text { code }\end{array}$} & \multirow{2}{*}{$\begin{array}{l}\text { Phenolic } \\
\text { compounds }\end{array}$} & \multirow[b]{2}{*}{ Tannin } & \multicolumn{2}{|c|}{ Alkaloid } & \multirow{2}{*}{$\begin{array}{l}\text { Isolates } \\
\text { code }\end{array}$} & \multirow{2}{*}{$\begin{array}{l}\text { Phenolic } \\
\text { compounds }\end{array}$} & \multirow{2}{*}{ Tannin } & & \multicolumn{2}{|c|}{ Alkaloid } & \multirow{2}{*}{$\begin{array}{l}\text { Isolates } \\
\text { code }\end{array}$} & \multirow{2}{*}{$\begin{array}{l}\text { Phenolic } \\
\text { compounds }\end{array}$} & \multirow{2}{*}{ Tannin } & \multicolumn{2}{|c|}{ Alkaloid } \\
\hline & & & Wagner's & Hager's & & & & & Wagner's & Hager's & & & & Wagner's & Hager's \\
\hline CSU3 & - & - & - & - & CSU17 & - & + & & - & - & CSP30 & - & + & - & + \\
\hline CSU4 & - & + & - & - & CSU18 & - & + & & - & + & CSP31 & - & + & - & + \\
\hline CSU5 & - & - & - & - & CSU19 & - & + & & + & + & CSP34 & - & + & + & + \\
\hline CSU6 & - & + & - & + & CSU21 & - & + & & - & + & CSP37 & - & + & - & + \\
\hline CSU7 & - & - & - & + & CSU23 & - & + & - & - & + & CSP38 & - & + & - & - \\
\hline CSU8 & - & + & - & + & CSU24 & - & + & & - & - & CSP39 & - & + & - & + \\
\hline CSU9 & - & + & - & \pm & CSU26 & - & + & & - & + & CSP40 & - & + & - & - \\
\hline CSU10 & - & + & - & - & CSU27 & - & + & & - & + & CSP41 & - & + & - & + \\
\hline CSU12 & - & + & - & + & CSU29 & - & + & & - & - & CSP43 & - & + & - & + \\
\hline CSU13 & - & - & - & + & CSP1 & - & - & & - & + & CSP44 & - & - & - & + \\
\hline CSU15 & - & + & - & + & CSP22 & - & + & & + & & CSD2 & - & + & - & + \\
\hline CSU16 & - & - & - & - & & & & & & & & & & & \\
\hline
\end{tabular}

-, no activity; \pm , weak; +, positive activity. 
Pharmaceutically active secondary metabolites of newly isolated actinobacteria from two Cameroonian soils

Supplementary S4 Screening for natural products (phenolic compounds, tannin and alkaloids) in the crude metabolites of actinobacterial isolates recovered from polluted soil collected from Ngaoundere, Cameroon.

\begin{tabular}{|c|c|c|c|c|c|c|c|c|c|c|c|c|c|c|}
\hline \multirow{2}{*}{ Isolates code } & \multirow{2}{*}{$\begin{array}{l}\text { Phenolic } \\
\text { compounds }\end{array}$} & \multirow{2}{*}{ Tannin } & \multicolumn{2}{|c|}{ Alkaloid } & \multirow{2}{*}{$\begin{array}{c}\text { Isolates } \\
\text { code }\end{array}$} & \multirow{2}{*}{$\begin{array}{l}\text { Phenolic } \\
\text { compounds }\end{array}$} & \multirow{2}{*}{ Tannin } & \multicolumn{2}{|c|}{ Alkaloid } & \multirow{2}{*}{$\begin{array}{c}\text { Isolates } \\
\text { code }\end{array}$} & \multirow{2}{*}{$\begin{array}{l}\text { Phenolic } \\
\text { compounds }\end{array}$} & \multirow{2}{*}{ Tannin } & \multicolumn{2}{|c|}{ Alkaloid } \\
\hline & & & Wagner's & Hager's & & & & Wagner's & Hager's & & & & Wagner's & Hager's \\
\hline PSU1 & - & - & - & - & PSU30 & - & + & - & - & PSU45 & - & + & & + \\
\hline PSU2 & - & - & - & - & PSU33 & - & + & + & + & PSU46 & - & + & & - \\
\hline PSU4 & - & - & - & - & PSU34 & - & + & - & + & PSP3 & - & + & & - \\
\hline PSU5 & - & + & - & + & PSU35 & - & + & + & + & PSP14 & - & + & & + \\
\hline PSU7 & - & + & - & + & PSU36 & - & + & - & + & PSP19 & - & + & - & + \\
\hline PSU8 & - & + & - & + & PSU37 & - & + & - & + & PSP26 & - & + & - & + \\
\hline PSU9 & - & + & - & \pm & PSU38 & - & + & - & \pm & PSD20 & - & + & - & + \\
\hline PSU13 & - & + & - & - & PSU39 & - & + & - & + & PSD21 & - & + & - & + \\
\hline PSU18 & - & + & - & + & PSU40 & - & + & - & + & PSD23 & - & + & + & + \\
\hline PSU22 & - & + & - & + & PSU41 & - & + & - & + & PSD25 & - & + & - & + \\
\hline PSU24 & - & + & - & + & PSU42 & - & + & - & \pm & PSD31 & - & + & + & - \\
\hline PSU27 & - & + & - & + & PSU43 & - & + & + & + & PSD32 & - & + & & \pm \\
\hline PSU28 & - & - & - & - & PSU44 & - & + & & + & PSD47 & - & + & + & + \\
\hline
\end{tabular}




\section{المركبات الثانوية النشطة صيلانياً من الأكتينوبكتريا المعزولة من التربة الكاميرونية

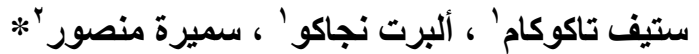

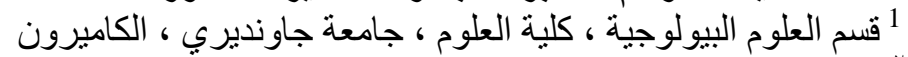

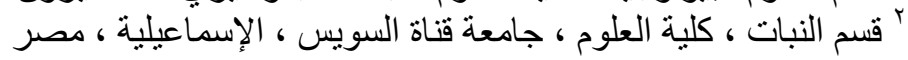 \\ الملخص العربي}

تعتبر الأمر اض المعدية السريرية من أهم مخاوف الصحة العامة في جميع أنحاء العالم، لا سيما في البلدان النامية ، حيث الوصول إلى الرعاية الصحية محدود للغاية وذاللك نتيجة لزيادة الكائنات الدقيقة المقاومة للمضادات الحيوية، ولذا فهنالك حاجة

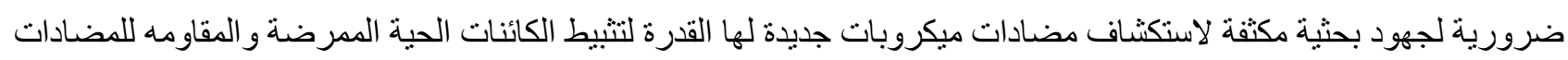

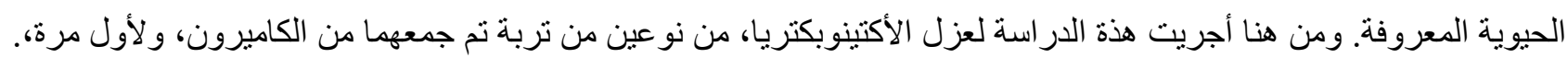

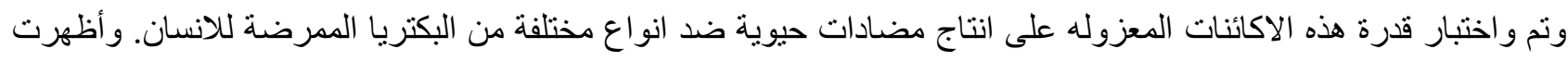

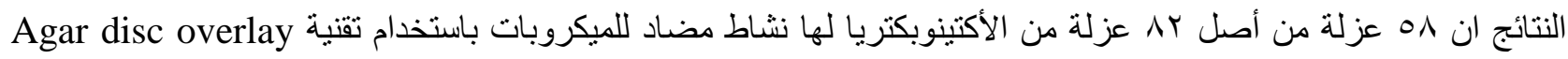

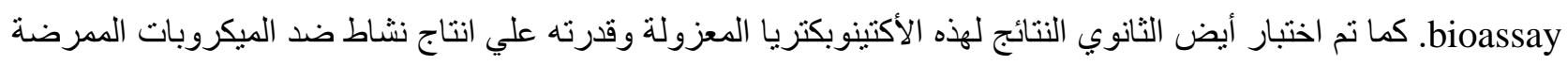
المستخدمه في هذه الدراسة باستخدام اختبار "agar disc diffusion test ". و أظهرت نتائج هذه الدراسه أن أكثر عزلات

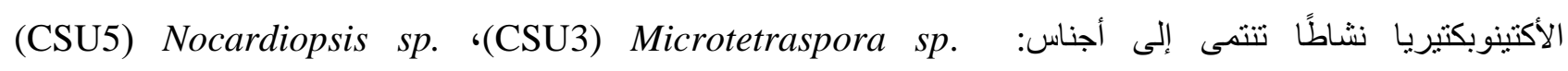
(CSD50) Micromonospora sp و و (CSP3, PSU28, PSU30 ) Streptomyces sp الاكثر انتشارًا تنتمي الي جنسي: Actinomadura sp. Streptomyces، حيث أنتجت مكونات ايضية ثانوية قوية ومضادة للميكروبات الممرضة، مما يؤكد إلى أن عزلات Streptomycete-phenotype توفر مكونات ايضية قوية مضاده للكائنات الممرضة و المقاومه للمضادات الحيوية وكذلك تفي للأغر اض الدوائيه حيث تم اختبار المركبات البيوكيميائية الطبيعية التي تفرز في الأوساط الغذائيه السائله و أثثتت وجود مركبات Alkaloids and tannin. 